\title{
Feeding and reproductive patterns of Astyanax intermedius in a headwater stream of Atlantic Rainforest
}

\author{
URSULLA P. SOUZA ${ }^{1}$, FABIO C. FERREIRA ${ }^{2}$, MICHELE A.F. CARMO ${ }^{3}$ and FRANCISCO M.S. BRAGA ${ }^{4}$ \\ ${ }^{1}$ Programa de Pós-Graduação em Sustentabilidade de Ecossistemas Costeiros e Marinhos, Universidade \\ Santa Cecília, Rua Cesário Mota, 08, Boqueirão, 11045-040 Santos, SP, Brasil \\ ${ }^{2}$ Departamento de Ciências do Mar, Universidade Federal de São Paulo, Campus Baixada Santista, \\ Av. Alm. Saldanha da Gama, 89, Ponta da Praia, 11030-400 Santos, SP, Brasil \\ ${ }^{3}$ Programa de Pós-Graduação em Sustentabilidade de Ecossistemas Costeiros e Marinhos, Laboratório de Pesquisa em \\ Recursos Pesqueiros, Universidade Santa Cecília, Rua Cesário Mota, 08, Boqueirão, 11045-040 Santos, SP, Brasil \\ ${ }^{4}$ Departamento de Zoologia, Instituto de Biociências, Universidade Estadual Paulista "Júlio de \\ Mesquita Filho", Av. 24-A, 1515, Bela Vista, 13506-910 Rio Claro, SP, Brasil
}

Manuscript received on December 12, 2014; accepted for publication on February 20, 2015

\begin{abstract}
In this paper, we determined diet composition, reproductive periodicity and fecundity of Astyanax intermedius in a headwater stream of a State Park of an Atlantic rainforest. We also evaluated the influence of rainfall, water temperature and fish size on niche width and niche overlap. Sampling was conducted monthly throughout one year in the Ribeirão Grande stream, southeastern Brazil. Diet consisted of 31 food items with equal contribution of allochthonous and autochthonous items. Females were larger than males, and the mean sizes at first maturation were $4.44 \mathrm{~cm}$ and $3.92 \mathrm{~cm}$, respectively. Based on 212 pairs of mature ovaries, the number of oocytes per female ranged from 538 to 6,727 (mean =2,688.7). Niche width and niche overlap were not related to rainfall nor water temperature and only niche width increased with fish size, suggesting that as fish grow, more items are included in diet. Our results suggested that $A$. intermedius fit as a typical opportunistic strategist which may explain the prevalence of this species in several isolated headwater basins of vegetated Atlantic forested streams where food resources are abundant and distributed throughout the year.
\end{abstract}

Key words: Characidae fishes, niche overlap, niche width, spawning type.

\section{INTRODUCTION}

In tropical riverine environments, where diversity of food is high and highly variable, there is a predominance of generalist and opportunistic fish species, reflecting the wide trophic adaptability

Correspondence to: Ursulla Pereira Souza

E-mail: upsouza@gmail.com of teleostei (Abelha et al. 2001). Research addressing variation in feeding habitats enables understanding how spatial and temporal changes in environmental factors affect the structure of fish populations (Esteves and Aranha 1999, Barreto and Aranha 2006). Another dimension of fish ecology is related to life history and reproductive patterns. Periodicity, reproductive effort and location of 
spawning habitats for example, are important for the understanding of how fish strive in specific environments, and which conservation actions are needed to preserve species and ecosystemic functions (Garutti 1989, Braga et al. 2006).

Headwater streams are inhabited by smallsized fish species, in general with restrict geographical distribution and high endemism (Castro and Menezes 2001). The occurrence and distribution of fish in small streams relates to the abundance of alimentary resources (Angermeier and Karr 1983) and the riparian vegetation is an important source of energy and material, providing the necessary conditions for fish feeding (ex. terrestrial invertebrates) and reproduction (ex. shade) (Wootton 1992, Henry et al. 1994). In addition, the riparian vegetation contributes to particulate organic material that is processed by aquatic invertebrates that are ingested by several fish species (Gregory et al. 1991, Esteves and Aranha 1999, Pusey and Arthington 2003).

Among small-sized fishes in Neotropic, the species within the "complex Astyanax scabripinnis" are restricted to headwaters of small streams (Britski 1972, Caramaschi 1986, Kavalco and Moreira-Filho 2003). This species complex was defined based on morphologic and karyotype variation (Moreira-Filho and Bertollo 1991) and seems to have evolved independently in different hydrographic basin, or even within a same hydrographic system, from isolated populations. Bertaco and Lucena (2006) named 15 species. Among them, A. intermedius Eigenmann, 1908 is distributed in the Paraíba do Sul River basin and coastal rivers of the state of Rio de Janeiro, Brazil (Lima et al. 2003). Most knowledge on $A$. intermedius relies on cytogenetic studies (Kavalco and Moreira-Filho 2003, Kavalco et al. 2004, 2007) whereas much of its life history and feeding behaviour remains to be elucidated.

Besides its generalist behaviour, Souza et al. (2015) showed evidences for trade-offs between energy assimilation and reproductive effort of $A$. intermedius. Although males had constant reproductive effort throughout the year, females reproductive effort increased with water temperature, which resulted in a depleted body condition. Gomiero et al. (2012) also verified that part of this population had small reproductive success because some individual are parasitized by an isopod that attaches on to fish tongue. These fishes had a significant depletion on body condition and gonad development probably due to a reduced capacity of feeding.

Thus, even for generalist species such as $A$. intermedius, the analysis of basic biological information provides insights on how environment affects population structure. In this paper, we determined diet composition of $A$. intermedius in a headwater stream of a State Park of Atlantic rainforest and described information on reproductive periodicity and fecundity. We also evaluated if niche width and niche overlap are related to rainfall, water temperature and fish size.

\section{MATERIALS AND METHODS}

\section{STUDY REGION AND ENVIRONMENTAL DATA}

Sampling was conducted monthly between January and December 2004 in the Ribeirão Grande stream $\left(23^{\circ} 26^{\prime} \mathrm{S}, 45^{\circ} 14^{\prime} \mathrm{W}\right)$, a headwater stream at 757 $\mathrm{m}$ elevation located inside the environmental protection area "Parque Estadual da Serra do Mar (PESM)", Santa Virginia Unit, southeastern Brazil. The sample stretch had clear water surrounded by natural vegetation and streambed composed by sand and rocks. Ribeirão Grande is a $4^{\text {th }}$ order stream (Strahler 1952) with a drainage area of 4.59 $\mathrm{km}^{2}$. It is a tributary of the Paraitinga river which originates the Paraíba do Sul river basin, one of the most impacted basins of southeast Brazil that crosses the states of São Paulo, Minas Gerais and Rio de Janeiro towards the Atlantic Ocean. Most park area is covered by pristine Atlantic rainforest with discontinuous patches of recovering native 
vegetation, abandoned eucalypt plantation, and small rural areas. The relief is predominantly mountainous with steep valleys characterizing the landscape. The tops of ridges are between 960 and $1160 \mathrm{~m}$ in the core park area, but reach a maximum of 1585 m elevation in the Ribeirão Grande stream subbasin (São Paulo 1998).

Climate in the region is humid subtropical. Historical data on rainfall $(R F)$ was extensive and available monthly from 1936 to 2010, from gauging stations in São Luiz do Paraitinga town $\left(23^{\circ} 13^{\prime} \mathrm{S}\right.$, $45^{\circ} 19^{\prime}$ W) $23 \mathrm{~km}$ distant from the sampling site. These data were used to characterize the regional climate. We also measured water temperature (WT) at each sampling in the Ribeirão Grande stream using a regular thermometer.

FISH SAMPLING AND BIONOMIC DATA

The fishes were collected with six gillnets (mesh sizes from 1.5 to $4.0 \mathrm{~cm}$ between adjacent knots), three funnel traps and a seine net $(2.0 \times 1.0 \mathrm{~m}$, mesh $=0.25 \mathrm{~cm}$ between adjacent knots). Sampling effort was standardized to $12 \mathrm{~h}$ for gillnets and funnel traps. Seine net effort was standardized as 10 pulls taken during the morning along patches of the submerged macrophyte Potamogeton polygonus Cham. and Schltdl., where the fishes concentrate. Due to water clarity, the seine net was the most efficient method whereas gillnets and funnel traps had low captures. Two other sites were sampled monthly during the same period in Paraibuna and Ipiranga rivers (Gomiero and Braga 2006), but yielded only 3 individuals of Astyanax intermedius, suggesting that the species does not have self-sustaining populations in those habitats. All procedures were approved by the Animal Ethics Committee at Santa Cecilia University (CEUA - UNISANTA), document CEUA UNISANTA 07/2015.

After each sampling, the fishes were fixed in formalin $10 \%$ and preserved in alcohol $70 \%$. Voucher specimens were deposited at the fish collection of Universidade Federal do Rio Grande do Sul (UFRGS 10821). In the laboratory we measured the standard length $(\mathrm{SL}-\mathrm{cm})$ and total weight $(\mathrm{TW}-\mathrm{g})$. Fishes were eviscerated and the sex and the stages of gonadal maturation (GM: immature/juveniles - A, maturing - B, fully mature $\mathrm{C}$ and spent - D) were verified based on size, shape, and degrees of vascularization and transparency (Vazzoler 1996, Alkins-Koo 2000).

The stomachs full of food were preserved in alcohol $70 \%$ and prey items identified to the lowest feasible taxonomic level using specialized literature (Borror and Delong 1969, Needham and Needham 1982, Costa et al. 2006). To quantify diet, we used the Feeding Preference Degree (FPD) index proposed by Braga (1999) which is a measure of alimentary preference for a group of individuals, and consists of attributing categories to the food items according to their relative abundance in the stomach. When there is only one food item the score of 4 is attributed. When there is more than one item the scores 3, 2 or 1 are adopted, according to the relative predominance of each item. FPD is calculated for each alimentary item through the sum of the attributed scores divided by the number of analyzed stomachs. The food items were subsequently classified as preferential $(\mathrm{FPD} \leq 2)$, secondary $(1 \leq$ FPD $<2)$ and occasional $(0<$ FPD $<1$ ) following Braga (1999).

To estimate fecundity all mature and spent ovaries were weighed, immersed in Gilson's solution and periodically shaken to dissociate the oocytes. Once separated, oocytes were preserved in $70 \%$ alcohol, and the number of oocytes was estimated according to volumetric method (Vazzoler 1996) by the expression $N=S \times n / s$, where $S$ is the volume of alcohol used to homogenize the mass of oocytes and $n$ is the total number of oocytes counted in a sample of $s$ volume obtained with a Stempel pipette $(2 \mathrm{~mL})$. A subsample of 100 oocytes was randomly selected from each ovary and measured using an ocular micrometric (at 10x magnification). The minimal diameter of 
mature oocytes was determined by their visual appearance (mature oocytes are opaque, West 1990) considering those greater than or equal to the size of the last mode of the distribution. Batch fecundity was then estimated as $F e c=p \times N$, where $p$ is the proportion of mature oocytes estimated within each ovary. This procedure, although not as precise as histological determination (West 1990), has been useful to allow fecundity estimation in fractional spawners (Braga et al. 2007, Gomiero et al. 2007, 2008a).

The spawning type was verified through the frequency distribution of oocyte sizes. The presence of a single mode of yolky oocytes is characteristic of a total spawner species whereas two or more modes characterize a fractional spawning type (Vazzoler 1996). Individuals with similar frequency distributions were grouped together and the gonadosomatic index (GSI) was calculated for each group according to the expression $G S I=\left(W_{O} / W_{T}\right) \times 100$, where $W_{O}$ is the ovarian weight and $W_{T}$ the total fish weight.

ANALYSES OF FEEDING

We calculated the niche breadth ( $\left.B^{\prime}\right)$ using Levins' index (Levins 1968) and the niche overlap $\left(\theta_{j k}\right)$ using Pianka index (Pianka 1973). These indices were calculated for each month to detect monthly changes related to rainfall level or water temperature, and for the size classes in order to detect ontogenetic changes in diversity and composition of alimentary items. The length of the size classes was $5 \mathrm{~mm}$.

Niche breadth $\left(B^{\prime}\right)$ and niche overlap $\left(\theta_{j k}\right)$ were calculated according to the formula:

$$
\begin{aligned}
& B^{\prime}=\left(\sum_{i=1}^{n} P_{i}^{2}\right)^{-1} \\
& \theta_{j k}=\left(\sum_{i=1}^{n} P_{j} \cdot P_{k}\right) /\left(\sum_{i=1}^{n} P_{j}^{2} \cdot \sum_{i=1}^{n} P_{k}^{2}\right)^{1 / 2}
\end{aligned}
$$

where $P_{i}$ is the proportional contribution of food item $i$ in the diet (estimated by the FPD), $\theta_{j k}$ is the symmetrical niche overlap between months (or size classes) $j$ and $k, P_{i j}$ is the proportion of the resource $i$ used in month (or size classes) $j, P_{i k}$ is the proportion of resource $i$ used in month $k$, and $n$ is the total number of food items.

A multiple regression model was used to test the dependence of monthly niche breadth on rainfall and water temperature, while a simple linear regression was used to test for changes in niche breadth related to size classes. Niche overlap was modeled as a function of rainfall, water temperature and size classes using Permutational Multivariate ANOVA (Anderson 2001, McArdle and Anderson 2001). The method is based on the partitioning of the sum-of-squares (SS) in a dissimilarity matrix so that a F statistic is calculated as the ratio of among and within groups SS. The analysis was done in $\mathrm{R}$ software using function "adonis", which is available in Vegan package (Oksanen et al. 2013). Significance probabilities were calculated from 10000 permutations of the raw data.

ANALYSES OF REPRODUCTION

Simple ANOVA was used to compare the standard length of immature, males and females. The length of first maturation was determined for males and females with a logistic regression model. The response variable was coded as 0 for immature $(\mathrm{GM}=\mathrm{A})$ and 1 for mature individuals $(\mathrm{GM}=\mathrm{B}$, $\mathrm{C}$ or D). The average length of first maturation was considered the one where $50 \%$ of the individuals were mature $\left(\mathrm{L}_{50}\right)$.

\section{RESULTS}

We collected 765 individuals of Astyanax intermedius and analyzed the food items of 86 full stomachs. The majority of fishes had empty (192) or partially full stomachs (487) and was not analyzed. Diet consisted of 31 food items. 
Regarding the origin, 13 items were autochthonous, 17 were allochthonous, and one of uncertain origin. Astyanax intermedius consumed mainly animal items such as insects of the Orders Coleoptera (adults), Hymenoptera (Formicidae) and Diptera (mainly Chironomidae larvae). Non-identified fragments of insects (i.e. abdomen, paws, wings, antennae) composed a high proportion of the food. Vegetal items such as algae (Batrachospermum sp. Roth, 1797), flowers, leaves, fruits and seeds occurred occasionally (Table I).

Niche breadth were not explained by rainfall $\left(\beta_{R F}=-0.013, \mathrm{p}=0.421\right)$ or water temperature $\left(\beta_{W T}\right.$ $=-0.007, \mathrm{p}=0.983)$. The multiple regression model with these two variables explained only $11 \%$ of total variation in niche breadth. On the other hand, the linear regression between size classes and niche breadth were highly significant $\left(\beta_{W T}=1.07, \mathrm{p}=\right.$ 0.001 ) explaining $61 \%$ of total variation in niche breadth. Niche overlap was also not explained by rainfall $(p=0.941)$, water temperature $(p=0.144)$ or size classes $(p=0.996)$ (Fig. 1).

REPRODUCTION

The standard length of Astyanax intermedius ranged from 2.0 to $9.0 \mathrm{~cm}$. Females were significantly larger than males and immature $\left(\bar{X}_{\text {females }}=7.24 \mathrm{~cm}\right.$, $s d=1.14 \mathrm{~cm}, \bar{X}_{\text {males }}=5.46 \mathrm{~cm}, \mathrm{sd}=1.23 \mathrm{~cm}, \bar{X}_{\text {immature }}$ $\left.=2.91 \mathrm{~cm}, \mathrm{sd}=0.61 \mathrm{~cm}, F_{762,2}=1210, p<0.001\right)$. The mean sizes at first maturation were $4.44 \mathrm{~cm}$ for females (95\% confidence interval from 3.46 to 5.64) and 3.92 for males (95\% confidence interval from 3.26 to 4.74 ) (Fig. 2). Although the value was higher for females, superposition of the confidence intervals suggest no significant differences.

We found mature individuals of $A$. intermedius throughout the year (Fig. 3) and analyzed 212 pairs of mature ovaries. The mature females ranged from 5.3 to $9.0 \mathrm{~cm}$ of standard length. The oocytes diameter ranged from 61.2 to $1,346.4 \mu \mathrm{m}$. Mature oocytes were considered those larger than $612 \mu \mathrm{m}$ (10 d.o.m.). Based on the size frequency distribution of oocytes 3 groups was recognized: i) ovaries with predomination of oocytes in final stages of maturation $\left(\mathrm{N}=42 ; \mathrm{GSI}_{\text {mean }}=7.06\right.$, sd $=2.05)$, ii) ovaries with mature oocytes $(\mathrm{N}=169$; $\left.\mathrm{GSI}_{\text {mean }}=12.58, \mathrm{sd}=5.00\right)$, and iii) one ovary recently spent $(\mathrm{N}=1 ; \mathrm{GSI}=5.75)$ (Fig. 4). The total number of oocytes, which corresponds to those at all stages of development, ranged from 1,125 to 10,350. The potential fecundity, represented by the mature oocytes that are effectively eliminated during spawning season, ranged from 538 to 6,727 (mean $=2,688.7, \mathrm{sd}=1278.8)$.

\section{DISCUSSION}

In the Atlantic Forest streams of southeast where seasonality is not well marked (no clear delimitation between dry and wet seasons), alimentary resources seem to be homogeneously distributed throughout the year (Gomiero et al. 2007). Although other studies indicate a seasonal variation along the year in the relative importance of autochthonous versus allochthonous items (Winemiller 1990), our results indicate that in Ribeirão Grande stream these food sources are equally important with a little preponderance of allochthonous items (55\%), mainly terrestrial insects.

Based on alimentary items, Astyanax intermedius was classified as omnivorous and generalists. In such species, an integration between a low alimentary preference with the availability and accessibility of food items that is provided by environment is expected (Angermeier and Karr 1983, Gerking 1994). Other fish species in the region such as Rhamdia quelen (Gomiero et al. 2007), Oligosarcus hepsetus (Botelho et al. 2007) and Brycon opalinus (Gomiero et al. 2008b), also ingested similar fractions of autochthonous and allochthonous items with predominance of Orders Coleoptera, Hymenoptera and Diptera (mainly Chironomidae larvae), suggesting that accessibility and availability play an important role in determining food items consumed. 
TABLE I

Food items found in stomachs of Astyanax intermedius and Feeding Preference Degree of each item (FPD) with the respective classification ( $N=86$ stomachs).

\begin{tabular}{|c|c|c|}
\hline Food items & FPD & Classification \\
\hline \multicolumn{3}{|l|}{ Autochthonous } \\
\hline Nematoda & 0.13 & occasional \\
\hline Mollusca & 0.03 & occasional \\
\hline Ephemeroptera - nymphs & 0.13 & occasional \\
\hline Odonata - nymphs & 0.12 & occasional \\
\hline Hemiptera Heteroptera - adults & 0.03 & occasional \\
\hline \multicolumn{3}{|l|}{ Diptera } \\
\hline larvae & 0.57 & occasional \\
\hline pupae & 0.24 & occasional \\
\hline \multicolumn{3}{|l|}{ Trichoptera } \\
\hline cocoons & 0.06 & occasional \\
\hline larvae & 0.03 & occasional \\
\hline pupae & 0.01 & occasional \\
\hline Scales & 0.02 & occasional \\
\hline Fish (fragments) & 0.03 & occasional \\
\hline Algae & 0.33 & occasional \\
\hline \multicolumn{3}{|l|}{ Allochthonous } \\
\hline Arachnida - Araneae & 0.12 & occasional \\
\hline Blattodea & 0.03 & occasional \\
\hline Isoptera & 0.02 & occasional \\
\hline Dermaptera & 0.03 & occasional \\
\hline \multicolumn{3}{|l|}{ Hemiptera Auchenorryncha } \\
\hline nymphs & 0.03 & occasional \\
\hline adults & 0.09 & occasional \\
\hline \multicolumn{3}{|l|}{ Coleoptera } \\
\hline larvae & 0.22 & occasional \\
\hline adults & 0.59 & occasional \\
\hline Diptera - adults & 0.24 & occasional \\
\hline Trichoptera - adults & 0.01 & occasional \\
\hline \multicolumn{3}{|l|}{ Lepidoptera } \\
\hline larvae & 0.14 & occasional \\
\hline adults & 0.03 & occasional \\
\hline Hymenoptera & 0.07 & occasional \\
\hline Hymenoptera - Formicidae & 0.58 & occasional \\
\hline \multicolumn{3}{|l|}{ Vegetable material } \\
\hline stems, flowers, leaves & 0.35 & occasional \\
\hline fruits & 0.05 & occasional \\
\hline seeds & 0.08 & occasional \\
\hline \multicolumn{3}{|l|}{ Unknown origin } \\
\hline Insects (fragments) & 1.51 & secundary \\
\hline
\end{tabular}
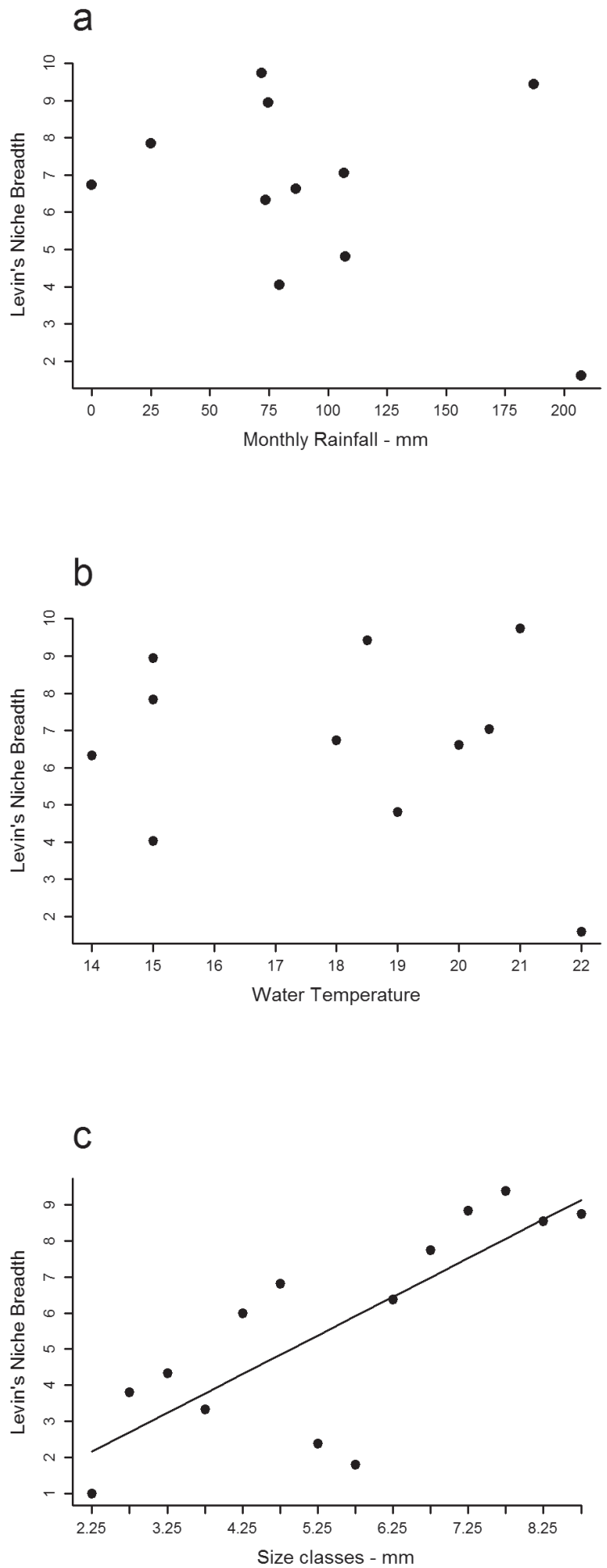

Figure 1 - Dispersion diagrams between Levin's niche breadth and monthly rainfall (a), water temperature $\left({ }^{\circ} \mathrm{C}\right)$ (b), and size classes (c). The estimated values for regression parameters in c were: $\beta_{0}=-0.24, \beta_{1}=1.07, F_{1,12}=19.17, p$ $=0.001, \mathrm{r}^{2}=0.615$. 

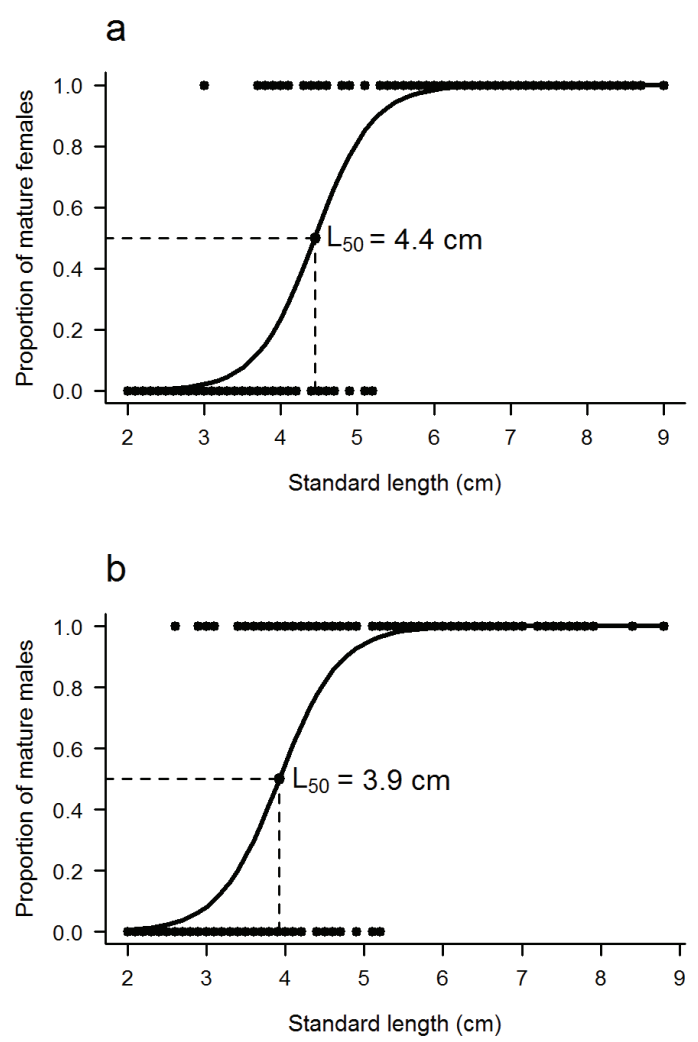

Figure 2 - Logistic regression curves for determination of the mean size of first maturation for females (a) and males (b) of Astyanax intermedius in Ribeirão Grande stream.

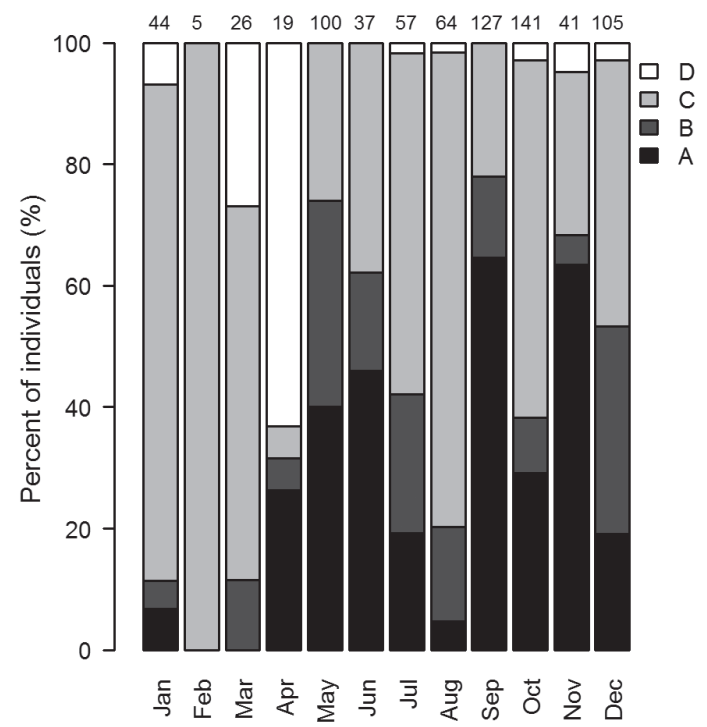

Figure 3 - Percent of individuals of Astyanax intermedius according to the stages of gonad maturation (immature/juveniles - A, maturing - B, fully mature - C and spent - D) in Ribeirão Grande stream. Numbers above bars represent the total of individuals captured per month.
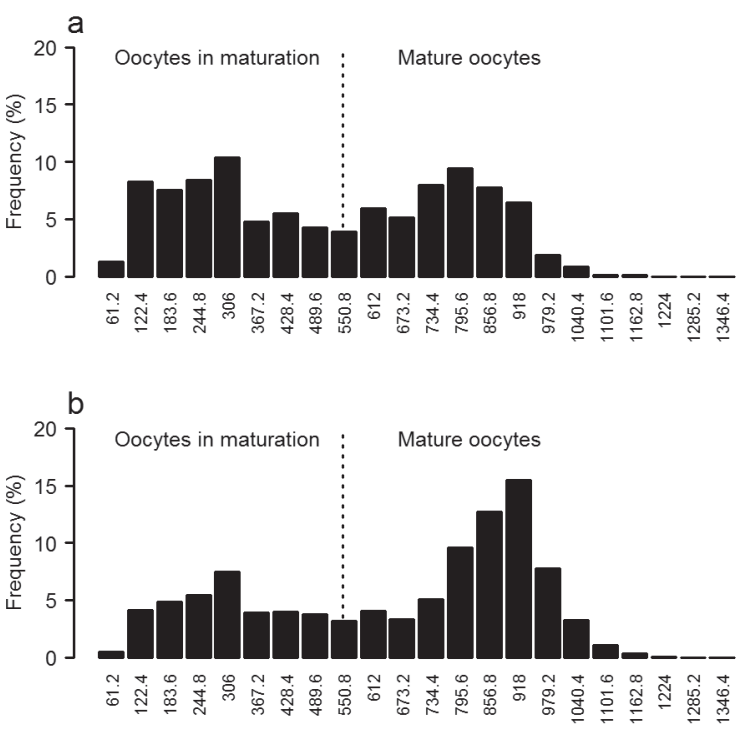

C

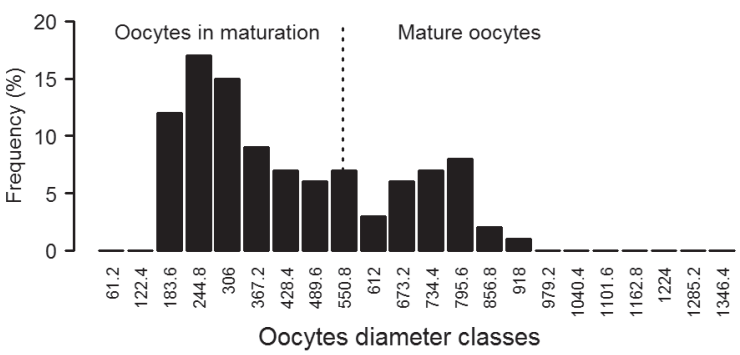

Figure 4 - Frequency distribution (\%) of oocytes diameters $(\mu \mathrm{m})$ in Astyanax intermedius. a - oocytes in early stages of maturation ( $\mathrm{N}=42$ females); $\mathbf{b}$ - oocytes in last stages of maturation ( $\mathrm{N}=169$ females) and $\mathbf{c}$ - oocyte distribution classes for a female after spawning $(\mathrm{N}=1)$.

Juvenile stages of Diptera, Ephemeroptera and Odonata are important authochthnous items in diet of stream fishes, while the allochthonous items consist mainly of plant material and terrestrial insects (Luiz et al. 1998). The importance of Diptera, mainly Chironomidae larvae, is high for stream fishes (Henry et al. 1994, Uieda and Gajardo 1996, Castro and Casatti 1997, Uieda et al. 1997, Casatti and Castro 1998, Motta and Uieda 2004, Oliveira and Bennemann 2005). These larvae are aquatic or semi-aquatic, indicating that part of the material exported to the terrestrial environment, after adults emergence, returns to aquatic ecosystem as alimentary source for fishes (Motta 1996, Roque 
et al. 2003), highlighting the role of aquatic insects for the stream food web structure (Uieda and Pinto 2011).

Rainfall and water temperature were not related to niche width or overlap agreeing with the generalist behaviour discussed so far. Nonetheless, the niche width (but not niche overlap) increased with fish size suggesting a diversification (but not a substitution) of food items consumed. This increase is probably related to a better capacity of exploring the available resources (ex. larger mouth and natatory capacity) (Truemper and Lauer 2005, Montaña et al. 2011) and were found for other Characidae species. In Mimagoniates microlepis for example, adults consumed more allochthonous items than juveniles (Barreto and Aranha 2006), and in Deuterodon langei, adults consumed more plant items (Vitule and Aranha 2002).

Females were significantly larger than males but size of first maturation were similar. Within the Characidae family it is common to find larger female maturation sizes similar to those found in the present study (Rodrigues et al. 1989, Barbieri and Barbieri 1988, Barbieri 1992a, b, Gurgel 2004, Hojo et al. 2004, Orsi et al. 2004, Mazzoni et al. 2005, Mazzoni and Silva 2006, Abilhoa 2007). In species with promiscuous mating and external fertilization, larger females are expected due to the positive relationship between female size and fecundity. Early maturation of males (Stearns 1992) is also expected, although this reproductive tatic is labile and strongly related to the interaction between genotype and environment (Wootton 1992). These species also invest a large proportion of assimilated resources to reproduction, decreasing the amount available for growth and survivor (Tedesco et al. 2008).

Female fecundity varied from 538 to 6,727 oocytes per female and was considered low if compared to its congeners such as $A$. bimaculatus with fecundity between 1,948 (Gennari Filho and Braga 1996) to 18,040 (Alkins-Koo 2000), or $A$. janeiroensis from 3,169 to 18,714 oocytes (Mazzoni et al. 2005). Nonetheless, fishes with mature gonad were found throughout the year suggesting an extended reproductive period for $A$. intermedius. The duration and time of the reproductive period are critical components of life-history strategy, and when environment allows, an extended reproduction with multiple batches of oocytes may increase the probability of recruitment throughout the year. In addition, small fishes tend to have this strategy as a result of space limitation, to produce a unique and large batch of oocytes. In addition, the extended reproductive season may reduce intraspecific competition for food in juveniles, and compensate the larger rates of eggs/larvae mortality due to unpredictable fluctuations in environmental conditions (Nikolskii 1969, Bagenal 1971, Kramer 1978, Matthews 1998, Braga et al. 2007).

The patterns of frequency distributions of oocytes diameters also suggested that the spawning was fractional as evidenced by the presence of two modes in the frequency of oocytes diameter distribution and by the gonad somatic index. In small Characidae the fractional spawning is common to other species as $A$. schubarti (Rodrigues et al. 1995), Bryconamericus iheringii (Lampert et al. 2004) and Moenkhausia intermedia (Braga and Gennari Filho 1991, Hojo et al. 2004) and probably results from adaptive pressures in streams environments (Mazzoni and Silva 2006).

All these results suggested that $A$. intermedius fit as a typical opportunistic strategist (Winemiller and Rose 1992) characterized by a small species, with early maturation, high mortality rates, multiple spawning, small eggs, low fecundity but high reproductive effort, rapid population turnover and capacity for rapid colonisation (Winemiller 1989, Lamouroux et al. 2002, Blanck et al. 2007). This may explain the prevalence of this species in several isolated headwater basins of vegetated Atlantic forested streams where food resources are abundant and distributed throughout the year. 


\section{ACKNOWLEDGMENTS}

This project was partially supported by the Conselho Nacional de Desenvolvimento Científico e Tecnológico (CNPq process 140180/2005-2) by means of a $\mathrm{PhD}$ scholarship provided to the first author, and by the Fundação de Amparo à Pesquisa do Estado de São Paulo (FAPESP process 04/12669-3) by providing funding for fieldwork. The Universidade Estadual Paulista (UNESP), Department of Biology, Rio Claro campus provided the institutional support. We thank Dr. Leandro M. Gomiero for providing logistical support during fieldwork and laboratory analyses, Dr. Heraldo A. Britski and Dr. Vinicius A. Bertaco for taxonomic identification and IBAMA (process 02027.000234/2005-05) for issuing the collection license.

\section{RESUMO}

Neste trabalho nós determinamos a composição da dieta, periodicidade reprodutiva e fecundidade de Astyanax intermedius em um riacho de cabeceira de um Parque Estadual de Mata Atlântica. Avaliamos também a influência da chuva, temperatura da água e tamanho do peixe na amplitude e sobreposição de nicho. As amostragens foram realizadas mensalmente ao longo de um ano no riacho Ribeirão Grande, sudeste do Brasil. A dieta consistiu de 31 itens, com igual contribuição de itens alóctones e autóctones. As fêmeas foram maiores do que os machos e os comprimentos médios de primeira maturação foram de 4,44 $\mathrm{cm}$ e $3,92 \mathrm{~cm}$, respectivamente. Com base nos 212 pares de ovários analisados, o número de ovócitos por fêmea variou de 538 a 6727 (média $=2688,7)$. A amplitude e a sobreposição de nicho não foram relacionadas à chuva e temperatura da água, e somente a amplitude de nicho aumentou com o tamanho do peixe, sugerindo que conforme o crescimento, mais itens são incluídos na dieta. Nossos resultados sugerem que $A$. intermedius apresenta um comportamento típico de espécie oportunista, o que pode explicar a prevalência desta espécie em diversos riachos de cabeceiras isolados de Mata Atlântica onde os recursos alimentares são abundantes e distribuídos ao longo do ano.

Palavras-chave: peixes Characidae, sobreposição de nicho, amplitude de nicho, tipo de desova.

\section{REFERENCES}

Abelha MCF, Agostinho AA AND Goulart E. 2001. Plasticidade trófica em peixes de água doce. Acta Scietiarum 23: 425-434.

ABILHOA V. 2007. Aspectos da história natural de Astyanax scabripinnis (Teleostei, Characidae) em um riacho de floresta com araucária no sul do Brasil. Rev Bras Zool 24: 997-1005.

ALKINS-KoO M. 2000. Reproductive timing of fishes in a tropical intermittent stream. Environ Biol Fish 57: 49-66.

ANDERSON MJ. 2001. A new method for non-parametric multivariate analysis of variance. Austral Ecol 26: 32-46.

ANGERMEIER PL AND KARR JR. 1983. Fish communities along environmental gradients in a system of tropical streams. Environ Biol Fish 9: 117-135.

BAGENAL TB. 1971. The interrelation of the size of fish eggs, the date of spawning and the production cycle. J Fish Biol 3: 207-219.

BARBIERI G. 1992a. Biologia de Astyanax scabripinnis paranae (Characiformes, Characidae) do Ribeirão do Fazzari. São Carlos. Estado de São Paulo. I. Estrutura populacional e crescimento. Rev Bras Biol 52: 579-588.

BARBIERI G. 1992b. Biologia de Astyanax scabripinnis paranae (Characiformes, Characidae) do Ribeirão do Fazzari. São Carlos. Estado de São Paulo. II. Aspectos quantitativos da reprodução. Rev Bras Biol 52: 589-596.

BARBIERI G AND BARBIERI MC. 1988. Curva de maturação, tamanho de primeira maturação gonadal e fecundidade de Astyanax bimaculatus e Astyanax fasciatus, na represa do Lobo, Estado de São Paulo (Osteichthyes, Characidae). Rev Ceres 35: 64-77.

BARRETO AP AND ARANHA JMR. 2006. Alimentação de quatro espécies de Characiformes de um riacho da Floresta Atlântica, Guaraqueçaba, Paraná, Brasil. Rev Bras Zool 23: 779-788.

BERTACO VA AND LUCENA CAS. 2006. Two new species of Astyanax (Ostariophysi: Characiformes: Characidae) from eastern Brazil, with synopsis of the Astyanax scabripinnis species complex. Neotrop Ichthyol 4: 53-60.

BLANCK A, TEDESCO PA AND LAMOUROUX N. 2007. Relationships between life-history strategies of European 
freshwater fish species and their habitat preferences. Freshwater Biol 52: 843-859.

BORROR DJ AND DELONG DM. 1969. Introdução ao estudo de insetos. São Paulo: Edgard Blücher Ltda, 653 p.

Botelho MLLA, GOMIERO LM AND BRAGA FMS. 2007. Feeding of Oligosarcus hepsetus (Cuvier, 1829) (Characiformes) in the Serra do Mar State Park - Santa Virgínia Unit, São Paulo, Brazil. Braz J Biol 67: 741-748.

BRAGA FMS. 1999. O grau de preferência alimentar: um método qualitativo e quantitativo para o estudo do conteúdo estomacal de peixes. Acta Scientiarum 21: 291-295.

BRAGA FMS AND GENNARI FILHO O. 1991. Estudos sobre a fecundidade, desova e mortalidade natural de Moenkhausia intremedia (Characidae, Tetragonopterinae), na represa de Barra Bonita, rio Piracicaba, SP. Naturalia 16: 55-68.

BRAGA FMS, SOUZA UP AND CARMASSI AL. 2007. Dinâmica populacional de Characidium lauroi e C. alipioi (Teleostei, Crenuchidae) na microbacia do Ribeirão Grande, serra da Mantiqueira Oriental, Estado de São Paulo. Acta Sci Biol Sci 29: 281-287.

BRAGA MR, MENEZES MS AND ARANHA JMR. 2006. Táticas reprodutivas de Mimagoniates microlepis (Steindachner, 1876) (Characidae, Glandulocaudinae) no rio Colônia Pereira, Paranaguá, Paraná. Estud Biol 28: 13-20.

BRITSKI HA. 1972. Peixes de água doce do Estado de São Paulo. Sistemática. In: Comissão Internacional da Bacia do Paraná-Uruguai: Poluição e Piscicultura (Ed), São Paulo: Faculdade de Saúde Pública da USP/Instituto de Pesca, p. 79-107.

CARAMASCHI EP. 1986. Distribuição da ictiofauna de riachos das bacias do Tietê e do Paranapanema, junto ao divisor de águas (Botucatu, SP). Tese de Doutorado, UFSCar, 245 p.

CASATTI L AND CASTRO RMC. 1998. A fish community of the São Francisco Rivers headwaters riffles, southeastern Brazil. Ichthyol Explor Fres 9: 229-242.

CASTRO RMC AND CASATTI L. 1997. The fish fauna from small forest stream of the upper Paraná River basin, southeastern Brazil. Ichthyol Explor Fres 7: 337-352.

CASTRO RMC AND MENEZES NA. 2001. Estudo diagnóstico da diversidade de peixes do estado de São Paulo. Biota: Série biodiversidade do estado de São Paulo. <http://www. biota.org.br/Link?livros.biota+Peixes+volseis+Diagnostic o>. Accessed October 10, 2014.

COSTA CC, IDE S AND SIMONKA CE. 2006. Insetos Imaturos: metamorfose e identificação. Ribeirão Preto: Holos Editora, 249 p.

ESTEVES KE AND ARANHA JMR. 1999. Ecologia trófica de peixes de riachos. In: Caramaschi EP, Mazzoni R and Peres-Neto PR (Eds), Oecologia Brasiliensis: Ecologia de Peixes de Riachos, Rio de Janeiro: Programa de PósGraduação em Ecologia, UFRJ, p. 157-182.

GARUTTI V. 1989. Contribuição ao conhecimento reprodutivo de Astyanax bimaculatus (Ostariophysi, Characidae), em cursos de água da bacia do Rio Paraná. Rev Bras Biol 49: 489-495.

GENNARI FILHO O AND BRAGA FMS. 1996. Fecundidade e desova de Astyanax bimaculatus e A. schubarti (Characidae, Tetragonopterinae) na represa de Barra Bonita, rio Piracicaba (SP). Revista Unimar 18: 241-254.

GERKING SD. 1994. Feeding ecology of fish. Califórnia: Academic Press, 416 p.

GOMIERO LM AND BRAGA FMS. 2006. Diversity of the ichthyofauna in the Serra do Mar State Park-Núcleo Santa Virgínia, São Paulo State, Brazil. Acta Sci Biol Sci 28: 213-218.

GOMIERO LM, GARUANA L AND BRAGA FMS. 2008a. Reproduction of Oligosarcus hepsetus (Cuvier, 1829) (Characiforms) in the Serra do Mar State Park, São Paulo, Brazil. Braz J Biol 68: 187-192.

GOMIERo LM, MANZATTO AG AND BRAGA FMS. 2008b. The role of riverine forests for food supply for the omnivorous fish Brycon opalinus Cuvier, 1819 (Characidae) in the Serra do Mar, southeast Brazil. Braz J Biol 68: 321-328.

Gomiero LM, SouzA UP AND BRAGA FMS. 2007. Reprodução e alimentação de Rhamdia quelen (Quoy \& Gaimard, 1824) em rios do Núcleo Santa Virgínia, Parque Estadual da Serra do Mar, São Paulo, SP. Biota Neotrop 7: $1-7$

GOMIERo LM, SOUZA UP AND BRAGA FMS. 2012. Condition factor of Astyanax intermedius Eigenmann, 1908 (OSTEICHTHYES, CHARACIDAE) parasitised by Paracymothoa astyanaxi Lemos de Castro, 1955 (CRUSTACEA, CYMOTHOIDAE) in the Grande River, Serra do Mar State Park - Santa Virgínia Unit, São Paulo, Brazil. Braz J Biol 72: 379-388.

GREGORY SV, SWANSON FJ, MCKEE WA AND CUMmins KW. 1991. An Ecosystem Perspective of Riparian Zones. Biosc J 41: 540-551.

GURGEL HCB. 2004. Estrutura populacional e época de reprodução de Astyanax fasciatus (Cuvier) (Characidae, Tetragonopterinae) do Rio Ceará Mirim, Poço Branco, Rio Grande do Norte, Brasil. Rev Bras Zool 21: 131-135.

HENRY R, UIEDA VS, AFONSO AAO AND KIKUCHI RM. 1994. Input of allochthonous and structure of fauna in a Brazilian headstream. Verh Internat Verein Limnol 25: 1866-1870.

HOJO RES, SANTOS GB AND BAZZOLI N. 2004. Reproductive biology of Moenkhausia intermedia (Eigenmann) (Pisces, Characiformes) in Itumbiara reservoir, Goiás, Brazil. Rev Bras Zool 21: 519-524.

KAVALCO KF AND MOREIRA-FILHO O. 2003. Cytogenetical analyses in four species of the genus Astyanax (Pisces, Characidae) from Paraíba do Sul River Basin. Caryologia 56: 453-461.

KaVAlCO KF, PAZZA R, BERTOLLO LAC AND MOREIRAFILHO O. 2004. Gene mapping of 5S rDNA sites in eight fish species from the Paraíba do Sul river basin, Brazil. Cytogenet Genome Res 106: 107-110. 
KaVAlCo KF, PAZZA R, BERTOLlo LAC AND MOREIRAFILHO O. 2007. Satellite DNA sites in four species of the genus Astyanax (Teleostei, Characiformes). Genet Mol Biol 30: 529-535.

KRAMER DL. 1978. Reproductive seasonality in the fishes of a tropical stream. Ecology 59: 976-985.

LAmourouX N, PofF NL AND ANGERMEIER PL. 2002. Inter-continental convergence of stream fish community traits along geomorphic and hydraulic gradients. Ecology 83: 1792-1807.

LAMPERT VR, AZEVEDo MA AND FialHo CB. 2004. Reproductive biology of Bryconamericus iheringii (Ostariophysi: Characidae) from rio Vacacaí, RS, Brazil. Neotrop Ichthyol 2: 209-215.

LEVINS R. 1968. Evolution in Changing Environments: Some Theoretical Explorations. New York: Princeton University Press, 132 p.

LIMA FCT ET AL. 2003. Genera Incertae Sedis in Characidae. In: Reis RE, Kullander SO and Ferraris Jr CJ (Eds), Check list of the fresh-water fishes of south and central America, Porto Alegre: Edipucrs, p. 106-169.

Luiz EA, Agostinho AA, Gomes LC AND HAHN NS. 1998. Ecologia trófica de peixes em dois riachos da Bacia do Rio Paraná. Rev Bras Biol 58: 273-285.

MATTHEWS WJ. 1998. Patterns in Freshwater Fish Ecology. New York: Chapman and Hall, 756 p.

MAZzoni R, MEndonÇA RS AND CARAmaschi EP. 2005. Reproductive biology of Astyanax janeiroensis (Osteichthyes, Characidae) from the Ubatiba river, Maricá, RJ, Brazil. Braz J Biol 65: 643-649.

MAZZONI R AND SILVA APF. 2006. Aspectos da história de vida de Bryconamericus microcephalus (Miranda Ribeiro) (Characiformes, Characidae) de um riacho costeiro de Mata Atlântica, Ilha Grande, Rio de Janeiro, Brasil. Rev Bras Zool 23: 228-233.

MCARDLE BH AND ANDERSON MJ. 2001. Fitting multivariate models to community data: A comment on distance-based redundancy analysis. Ecology 82: 290-297.

MONTAÑA CG, LAYMAN CL AND WINEMILLER KO. 2011. Gape size influences seasonal patterns of piscivore diets in three Neotropical rivers. Neotrop Ichthyol 9: 647-655.

MOREIRA-FILHO O AND BERTOLlo LAC. 1991. Astyanax scabripinnis (Pisces, Characidae): a species complex. Rev Bras Genet 14: 331-357.

MOTTA RL. 1996. Trama alimentar das comunidades animais em um curso de água corrente (Ribeirão do Atalho, Itatinga - SP). Dissertação de Mestrado. Programa de Pósgraduação em Zoologia, UNESP. (Unpublished).

MOTTA RL AND UIEDA VS. 2004. Diet and trophic groups of an aquatic insect community in a tropical stream. Braz J Biol 64: 809-817.
NEEDHAM JG AND NEEDHAM PR. 1982. Guia para el studio de los seres vivos de las agues dulces. Barcelona: Reverté, $131 \mathrm{p}$.

NIKOLSKII GV. 1969. Theory of Fish Population Dynamics: as the Biological Background for Rational Exploitation and Management of Fishery Resources. Edinburgh: Oliver and Boyd Ltd, $321 \mathrm{p}$.

OKSANEN J, BLANCHET FG, LEGENDRE P, MinCHIN PR, O'HARA RB, SIMPSON GL, SOLYMOS P, STEVENS MHH AND WAGNER H. 2013. Vegan: community ecology package. version 2.0-10. < http://CRAN.R-project.org/ package $=$ vegan $>$. Accessed November 20, 2014.

OLIVEIRA CO AND BENNEMANN ST. 2005. Ictiofauna, recursos alimentares e relações com as interferências antrópicas em um riacho urbano no sul do Brasil. Biota Neotrop 5: 1-13.

ORSI ML, CARVAlHO E AND FORESTI F. 2004. Biologia populacional de Astyanax altiparanae Garutti \& Britski (Teleostei, Characidae) do médio Rio Paranapanema, Paraná, Brasil. Rev Bras Zool 21: 207-218.

PIANKA ER. 1973. The structure of lizard communities. Ann Rev Ecol Syst 4: 53-74.

PUSEY BJ AND ARTHINGTON AH. 2003. Importance of the riparian zone to the conservation and management of freshwater fish: a review. Mar Freshwater Res 54: 1-16.

Rodrigues AM, RODRIGUES JD, CAMPOS EC AND FERREIRA AE. 1989. Aspectos da estrutura populacional e época de reprodução do tambiú Astyanax bimaculatus (Characiformes, Characidae) na represa de Bariri, rio Tietê, Estado de São Paulo, Brasil. B Inst Pesca 16: 97110.

RODRIGUES AM, SANTOS RA, GIAMAS MTD, CAMPOS EC AND CAMARA JJC. 1995. Tipo de desova e fecundidade do lambari prata Astyanax schubarti Britski, 1964 (Pisces, Characiformes, Characidae) na represa de Ibitinga, Estado de São Paulo, Brasil. B Inst Pesca 22: 133-139.

RoQue FO, PAPINELli M, Fragoso EM, FERREIRA WA, BARILLARI PR, YOSHINAGA MY, TRIVINHO-STRIXINO S, FENERICH-VERANI AND LIMA MIS. 2003. Ecologia de macroinvertebrados, peixes e vegetação ripária de um córrego de primeira ordem em região de Cerrado, do estado de São Paulo (São Carlos, SP). In: Henry R (Org), Ecótonos nas Interfaces dos Ecossistemas Aquáticos, São Paulo: Editora Rima, p. 313-338.

SÃo PAUlO. 1998. Planos de Manejo das Unidades de Conservação: Parque Estadual da Serra do Mar - Núcleo Santa Virgínia. Secretaria do Meio Ambiente. Governo do Estado de São Paulo, 128 p.

SOUZA UP, FERREIRA FC, BRAGA FMS AND WINEMILLER KO. 2015. Feeding, body condition and reproductive investment of Astyanax intermedius (Characiformes, Characidae) in relation to rainfall and temperature in a Brazilian Atlantic Forest stream. Ecol Freshw Fish 24: 123-132. 
STEARNS SC. 1992. The evolution of life histories. New York: Oxford University Press Inc, 249 p.

STRAHLER AN. 1952. Hypsometric (Area-Altitude) analysis of erosional topography. Bull Geol Soc Am 63: 1117-1142.

Tedesco PA, Hugueny B, OBERdorfF T, DÜRR HH, MÉRIGOUX S AND DE MÉRonA B. 2008. River hydrological seasonality influences life history strategies of tropical riverine fishes. Oecologia 156: 691-702.

TRUEMPER HA AND LAUER TE. 2005. Gape limitation and piscine prey size-selection by yellow perch in the extreme southern area of Lake Michigan, with emphasis on two exotic prey items. J Fish Biol 66: 135-149.

UIEDA VS, BUZZATO P AND KIKUCHI RM. 1997. Partilha de recursos alimentares em peixes em um riacho de serra do Sudeste do Brasil. An Acad Bras Cienc 69: 243-252.

UIEDA VS AND GAJARDO ICSM. 1996. Macroinvertebrados perifíticos encontrados em poções e corredeiras de um riacho. Naturalia 21:31-47.

UIEDA VS AND PINTO TLF. 2011. Feeding selectivity of ichthyofauna in a tropical stream: space-time variations in trophic plasticity. Community Ecol 12: 31-19.
VAZZOLER AEAM. 1996. Biologia da reprodução de peixes teleósteos: Teoria e Prática. Maringá: EDUEM, SBI, São Paulo, 169 p.

VITULE JRS AND ARANHA JMR. 2002. Ecologia alimentar do lambari, Deuterodon langei Travassos, 1957 (Characidae, Tetragonopterinae), de diferentes tamanhos em um riacho da Floresta Atlântica, Paraná (Brasil). Acta Biol Par 31: 137-150.

WEST G. 1990. Methods of assessing the ovarian development fishes: a review. Aust J Mar Freshw Res 41: 199-222.

WINEMILLER KO. 1989. Patterns of variation in life history among South American fishes in seasonal environments. Oecologia 81: 225-241.

WINEMILLER KO. 1990. Spatial and temporal variation in tropical fish trophic networks. Ecol Monogr 60: 331-367.

WINEMILLER KO AND ROSE KA. 1992. Patterns of life-history diversification in North American fishes: implications for population regulation. Can J Fish Aquat Sci 49: 21962218.

WoOTON RJ. 1992. Fish Ecology. $1^{\text {st }}$ ed., New York: Chapman and Hall, $212 \mathrm{p}$. 